
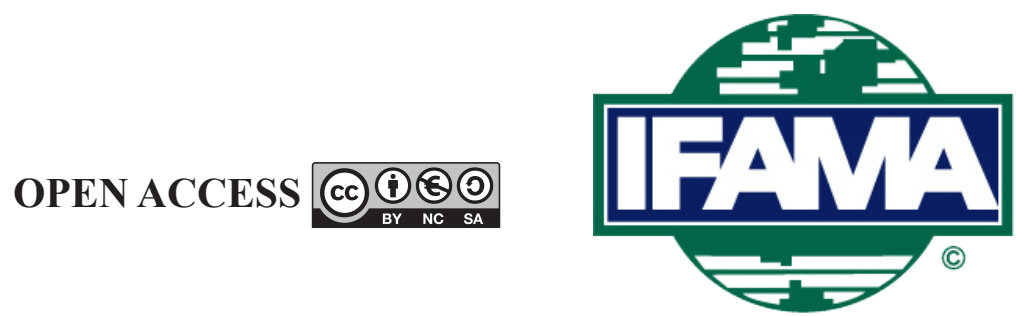

International Food and Agribusiness Management Review

Volume 24, Issue 6, 2021; DOI: 10.22434/IFAMR2020.0167

Received: 21 September 2020 / Accepted: 3 November 2020

Special Issue: IFAMA 2020 symposium

\title{
The role of innovation intermediary organisations in forming value creating meetings: the agri-food firm perspective \\ RESEARCH ARTICLE
}

\author{
Lisa Blix Germundsson ${ }^{\mathrm{a}}$, Per Frankelius ${ }^{\mathrm{b}}$ and Charlotte Norrman ${ }^{\circledR \mathrm{c}}$ \\ ${ }^{a}$ PhD student, Department of Work Science, Business Economics and Environmental Psychology, \\ Swedish University of Agricultural Sciences, Box 88, 25053 Alnarp, Sweden \\ ${ }^{b}$ Associate professor, ${ }^{c}$ Associate professor, Department of Management and \\ Engineering, Linköping University, 58183 Linköping, Sweden
}

\begin{abstract}
The aim of this study is to explore the concept of value creating meetings that connect agri-food firms with other crucial actors with whom they can collaborate or co-innovate, and related to this, examine the role of innovation intermediary organisations in the forming of such value creating meetings. The research design involves three case studies of intermediary organisations, within the agri-food sector in Sweden, each with an adherent case of a value creating meeting. The method comprises data collected through documents, interviews and insider accounts. The findings include the notion that three factors - problem, professionals and platform - are important to combine in order to facilitate value creation. We also show that intermediaries play an important role in the value creation process and that this process could be summarised into four steps: problem recognition, contact creation, dialogue facilitation and value creation. We elaborate on the role of innovation intermediaries, give examples of how value creating meetings could be arranged and what such meetings can lead to in case of outcome. Practical implications for policy makers and agri-food business firms include that intermediary organisations can play an important bridging role in a complex and fragmented context, offering contacts, networks and value creating meetings for targeted actors. Intermediary organisations need to focus on forming value creating meetings, work actively across sectoral boundaries, and allocate adequate resources for mediating efforts.
\end{abstract}

Keywords: agriculture, food, innovation brokering, agricultural innovation system, VUCA JEL code: O30, Q10

\footnotetext{
${ }^{\circledR}$ Corresponding author: charlotte.norrman@liu.se
} 


\section{Introduction}

Operating on a competitive global market, the agri-food sector faces considerable challenges to the agri-food business actors. Besides price competition, there has been a steady increase in the demands for food safety, product quality, sustainability, animal welfare and data/information accompanying products. This, in turn, has resulted in reinforced laws and regulations around agriculture and food in many countries. Handling these challenges have put the sector in an astonishingly complex context (cf. Hertel, 2015; Reinert, 2015).

To meet these challenges, the development of new knowledge and innovation is seen as crucial (OECD, 2019). However, the ambition to gain new knowledge and work efficiently with innovation poses several problems, especially for the many small and medium-sized business firms of the agri-food sector. In this regard, supportive knowledge and innovation systems have been put forward as vital (OECD, 2019). Also the European Commission encourages enhanced knowledge flows and boosted links between research and practice to strengthen the agricultural knowledge and innovation system, AKIS (EU SCAR, 2019). The scientific literature on agricultural innovation systems brings forward the role of innovation intermediary organisations and innovation support services as bridging elements for enhancing innovation and knowledge flows between multiple actors in the agri-food sector (Klerkx and Leeuwis, 2008).

Consequently, the OECD and the European Commission are discussing three kinds of central actors in the agri-food system. The first kind is actors comprising 'knowledge resources' that can be useful for development of food production. The second kind is actors that can implement new knowledge and concepts for improved food production; 'firms in the agri-food sector'. However, firms in other sectors seem to be equally important, as agronomy and food science needs to increase their efforts to join forces with technology, engineering and other relevant expertise. The third kind is actors that can bridge the assumed gap between knowledge resource actors and the implementing actors. These bridging actors are called 'innovation intermediaries, innovation support services', or similar names. Bridging actors are extra important for brokering networks with other sectors of expertise (Curran et al., 2010).

To succeed in innovation, awareness of other actors in the innovation system is important (Adner, 2006). This implies that innovating firms have to see beyond their own execution and regard the processes of the actors between themselves and their end customers. In the case of converging industries - such as agtech, which is a convergence of agriculture and technology, it becomes even more complicated as the actors need to understand the uncertainties and risks of other sectors and areas of expertise (Curran et al., 2010).

Today's multiple challenges, as described above, creates a context of highly complex and uncertain systems, which can be summarised as having entered the 'VUCA world'. According to Bennet and Lemoine (2014), this acronym stands for Volatility, Uncertainty, Complexity and Ambiguity. VUCA is one proposed paradigm that follows upon the previous linear industrial paradigm, which in turn replaced the local circular paradigm (ibid.). These paradigms could also be related to the steps of industrial development, where the first (mechanisation), second (the assembly line) and third (automation, PLC), industrial revolutions made society leave the local circular paradigm and move into the linear paradigm, that have been present during the last century (Zambon, 2019). Now entering the fourth (digitalisation, Internet of Things) and fifth (robotisation and autonomous systems) industry paradigm, coincides with entering the VUCA-paradigm that is described by Bennet and Lemoine (2014).

This situation calls for collaboration and the core of collaboration between various actors is the meetings between individuals from different organisations and backgrounds. The start of a dialogue between two such actors, initiates a process between them, where intentions, ideas, needs and competencies can be exchanged. If the dialogue is successful, 'value' in case of new thoughts and ideas that could form a base for inventive actions are formed. For such actions to occur, a relational process needs to evolve over time between the actors. 
Not all value creating meetings result in innovations; imitation and incremental steps as well as enlarged networks, new affairs, new business constellations or new knowledge, could also be valuable results of meetings. Besides, not all meetings result in anything valuable at all and to avoid this kind of waste, it is of interest to investigate how intermediary organisations operate to form meetings that they believe have potential to be valuable for the invited actors.

The aim of this study is therefore to explore the concept of value creating meetings that connect agri-food firms with other crucial actors with whom they can collaborate or co-innovate, and related to this, examine the role of innovation intermediary organisations in the forming of such value creating meetings.

An innovation intermediary organisation is, in the context of this paper, 'an organisation or body that acts as an agent or broker in any aspect of the innovation process between two or more parties' (Howells, 2006: 720). Being aware of the existence of innovation intermediaries without formal organisations, e.g. advisors and mentors that can act as facilitators of innovation; this study focuses on innovation intermediaries that are and act like formal organisations. A value creating meeting is defined as a meeting between two or more actors that creates an innovative process that results in an economic value, either in short or long term, for at least one of the actors.

To fulfil this aim, this study investigates the practices of three intermediary organisations in the agri-food industry, based in the two largest agri-food production areas in Sweden. The three cases are compared to elicit how they work to form value creating meetings. In addition, three examples of value creating meetings are included, where the intermediary organisations have played an important role and pinpoint the connection between these and the mentioned intermediary organisations. The research method comprises data collected through documents, interviews and insider accounts.

This paper is structured as follows. After the introduction (Section 1) follows a theoretical framework (Section 2), the method of the study (Section 3), and a presentation of the three case studies (Section 4). These are analysed and discussed (Section 5), and finally the conclusions are presented (Section 6).

\section{Theoretical framework}

If we depart from the theories of innovation systems (e.g. Edquist, 1997; Freeman, 1987; Lundvall, 1992), and view innovation as recombination (Schumpeter, 1934), meetings among actors in the system become essential (Howells, 2006). Innovation intermediaries are known to perform several activities, such as foresights, brokering between actors, mediating in collaborations, transferring of knowledge, helping with commercialisation, evaluation and validation of results (Howells, 2006; Winch and Courtney, 2007). Because they are perceived neutral, they are also regarded as able to contribute to systemic interaction (Klerkx and Leeuwis, 2009).

For the agri-food sector specifically, three functions of innovation intermediaries have been highlighted as important: demand articulation, network brokerage and innovation process management (Klerkx and Leeuwis, 2008). Demand articulation is explained as 'establishing a dialogue between users and producers' (ibid.: 262) to clarify both demand and supply, through analysing problems and facilitating the arrival at innovation strategies/plans (ibid.). Network brokerage is understood as helping SME's connect with external actors and resources such as financing (ibid.). Innovation process management comprises several activities such as managing relations to new and existing actors, knowledge brokerage, implementation and commercialisation (ibid.; Howells, 2006).

Ungureanu et al. (2018) link intermediary organisations to the turbulent development that in the introduction above were described as VUCA and concludes that intermediaries facilitate cooperation and hence could be means for organisations to be successful in a complex and uncertain world. According to Bennet and Lemoine (2014), the VUCA-world could be survived and its factors could be handled. 'Volatility' could be 
conquered by agility and flexibility, along with quality information to reduce 'uncertainty'. Internal company operations will need to be restructured to handle 'complexity', and the 'ambiguity' could be remedied by intelligent experimentation. Ability to cooperate across disciplinary borders will hence be essential. This is supported by Fleming and Waguespack (2007), who argues that the social capital of brokers and border spanning roles can unite open innovation communities and facilitate collaboration between organisations. Based upon these new conditions, collaboration among actors is put forward as the new logic (Ungureanu et al., 2018), since few actors will survive the battle in the VUCA world on their own. To foster collaboration, intermediary organisations play an important role by means of connecting actors with matching resources and competences. Thereby they can contribute to creation of collaboration-based business models (Norrman et al., 2020).

However, as argued by Frankelius (2009), meetings need to 'create value' if firms shall invest lots of time in them. Firms need to create value to be successful, thus they need to meet with other actors for knowledge, competencies, cooperation and innovation that creates value for the firm. It is proposed here to define value creation meeting in this context as a result from a meeting between two or more actors that creates an innovative process that results in an economic value, either in short or long term, for at least one of the actors. Direct results can be a business deal fulfilled in direct connection with the meeting. Indirect results can be new: (a) knowledge; (b) ideas; or (c) information about opportunities or risks in the external environment - that later contribute to the economic performance for some organisation involved in or related to the meeting. Empirically it is often easier to define value ex post than ex ante.

According to Frankelius (2009), actors that could combine, merge or fuse their knowledge, ideas and technologies into new combinations first need to be 'aware' of each other and the possible interesting resources of the actors, then 'reach' each other and 'start interacting'. Being part of networks created by e.g. intermediary organisations is a way to become aware of other actors. However, merely being aware of other actors is not enough; a fairly detailed knowledge of the actor and its resources and competencies is needed, to know whether a valuable collaboration could ensue. However, the next step 'reaching' is nothing to be taken for granted as the reason for this might not be obvious for the actors because there is no reason putting them together. Even in a situation where the actors have a 'true reason' to meet this may not be obvious for them as they lack this information and therefore cannot make a rational choice (Simon, 1945). Hence, some kind of 'substance' needs to create attention enough to start an action. It could be a problem, a need or some kind of opportunity and it has to be captured by an actor that knows who can create a solution. This third part actor, which could be labelled innovation intermediary, 'recognises the problem' and also has the motivation and capacity to promote and organise the meeting - and to persuade the actors to attend and thereby facilitate the 'contact creation'. If credibility is an issue, the intermediary also can take the role as credibility generator (Sanner, 1997), alternatively involve someone else to take this role.

Getting into contact is necessary but not enough for value to be created. With or without help from an innovation intermediary, it is needed for the actors involved to understand their 'offers' and 'needs' and here the intermediary could be instrumental in 'facilitating the dialogue' between the meeting actors that leads to such understanding. Sometimes this actor needs to overcome problems such as the involved actors represent different cultures, styles, assumptions and attitudes (Duarte and Snyder, 2001; Hofstede, 1996; Neff, 1995). It could also be needed (for the actors) to overcome cultural ${ }^{1}$ and disciplinary boundaries (Haslam, 2001).

Facilitating the dialogue may include to ease the actors' mutual learning about each other. In a successful dialogue, social learning is key (Blackmore et al., 2018). The learning between the actors should focus on four dimensions: (a) about the subject matter; (b) about the process; (c) about the other and the others' perspective; and (d) about oneself and one's own perspective (Daniels and Walker, 2001). This learning is necessary for successful meetings, in order to manage the complexity of the self-organising process

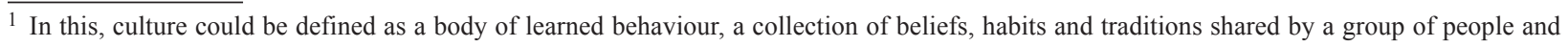
successively learned by people who enter society (Mead, 1951).
} 
that ensues between the actors ( ibid). A person that acts as a facilitator can also aid in handling any power elements that are present (Purdy, 2012).

\section{Methods}

The empirical material in this study consists of three intermediary organisations, each with an adherent case of a selected value creating meeting. The three intermediary organisations in the agri-food industry were chosen due to their presence in two of the largest agri-food production areas in Sweden. The adherent cases of value creating meetings were chosen as they embody several aspects relevant to value creating meetings.

The data is obtained through documents, interviews and insider accounts. Firstly, we build upon documents gathered from the three intermediary organisations, such as reports, evaluations and policy documents. Secondly, to gain deeper knowledge about the adherent value creating meetings, interviews were conducted with the persons involved. The interviews were performed as semi-structured interviews with in total six persons, in January through March 2020. Each interview took 30-60 minutes and was carefully note-taken.

Thirdly, as all three authors have been directly and indirectly engaged in the intermediary organisations used as cases, over the past ten years, we use these experiences as insider accounts. The first author of this study was operating manager of the intermediary organisation presented in Section 4.1, during the years of 20132018, and was present at the meeting in Section 4.1. The second author was a member of the board of one of the founding organisations for the intermediary organisation described in Section 4.2 and has since had a lot of contact with them. The third author has collaborated with the same intermediary for a long time, and together with the second author founded the intermediary organisation presented in Section 4.3.

Due to the authors' engagement in the intermediary organisations, this study has at least partly an autoethnographic method (Hayano, 1979). This was originally defined as a research approach where anthropologists conduct research on their own people rather than other peoples. The method describes building scientific knowledge based on self-perceived experiences. Thus, kinship exists with action research (Lewin, 1946). According to Humphreys (2005) autoethnographic vignettes aim to connect the researcher both as a writer and subject with the reader through an autobiographical account that allows readers to engage with the events narrated. The strength of this method is that it offers in-depth access to naturally occurring data in the form of informative situations, along with short- and long-term processes connected to the cases. The researcher gains a rich picture of the operations in its broader context, and detailed access to events as they happen (Gummesson, 1991). This familiarity and personal involvement naturally has drawbacks in comparison to a distant researcher, as it can cause bias and inappropriate considerations in the interpretation of the studied phenomena. This can be ameliorated if the researchers consciously strive to view the studied phenomena reflexively from a variety of angles and interpretative stances (Alvesson and Sköldberg, 2018). We are aware of the bias risk and have tried to keep our minds as open as possible.

\section{Results}

The intermediary organisations are situated in two of the largest agricultural production areas in Sweden; Skåne and Östergötland. The three cases differ in setup, operating level and regional context.

\subsection{SLU Partnership Alnarp}

SLU Partnership Alnarp started in 2004 as an intermediary organisation for collaboration between the Swedish University of Agricultural Sciences (SLU), and the agricultural, horticultural and forestry sectors in the south Sweden region (Blix Germundsson, 2020). Currently, the intermediary has around 90 partner organisations, ranging from small firms to large businesses and authorities. The main activities are threefold: (a) R\&D projects, jointly financed by the university and the intermediary partners; (b) meeting places such as subject groups, seminars, workshops and field excursions; and (c) students' thesis projects and a mentorship program. 
As the idea behind the intermediary was to connect the university with industry and society, the creation of meeting places between different actors is a core activity. The intermediary's organisational structure with a board and seven subject groups, provide for regular meetings between the university and the intermediary partners in seminars, workshops and field excursions. These meetings facilitate networking and individual contacts, and often give rise to new ideas (Blix Germundsson et al., 2020). The possibility of applying for seed funding for R\&D projects within the intermediary is valuable, as it enables financial support to develop ideas one step further for ideas that emanate from these meetings.

\section{- The biochar seminar}

In 2015 a seminar was initiated about the potentials of using biochar as an additive in soils. The seminar contained presentations by five researchers and two firms, and in the audience were an additional twelve firms, a nearby municipality administration, a research institute and ten university staff. The seminar ended with a workshop where concrete ideas and initiatives were discussed in smaller groups.

One of the firms had for some time entertained the idea of using husks from their seed production for producing biochar. They had made some trials in using agricultural soils and now found interesting results presented by a researcher studying biochar use in plant beds for urban trees and green areas in cities. Facilitated by the intermediary organisation, a dialogue between the firm and the researcher ensued in the workshop discussion after the seminar. Their dialogue grew into collaborative applications for external funding, to develop new knowledge and techniques regarding the production and use of biochar. Today a substantial research project is running and the firm has built a production of certified biochar of seed husks.

\subsection{Vreta Kluster}

Vreta Kluster is located outside Linköping in Östergötland county in east Sweden and was incepted in 2010 by the region, a number of prime-moving individuals and organisations, e.g. agricultural societies, an agricultural high school, a local property firm and the regional public authorities that wanted to see an increased collaboration and progress. Vreta Kluster has three pillars: firm park, meeting arena and arena for business development - in short, a physical place and a collaborative and innovative environment.

It offers business development, technology and product development, innovation management, innovation events, conference facilities, education, network and contact mediation, localities and flex-offices. The approach is open and inclusive and the main aim of Vreta Kluster is to be the natural node in the region for everything and everyone that has an interest in green industries, including farming, forestry, food, animal breeding, renewable energy, aquaculture and horticulture. Due to this Vreta Kluster becomes a natural hub for actors from green industries that seek contact with e.g. academia or trade and industry in general and for those outside the green industry that aims to reach this sector. Organising meetings has been at the core of the Vreta Kluster functioning since the inauguration and the meetings range from those organised between two or a few more individuals to big meetings (up to 150 persons), commonly organised in the form of seminars and conferences.

\section{- The rooster egg project}

In today's egg production, rooster chickens are sorted out and destroyed immediately after that they are hatched, while female chickens are saved to become egg producing hens. This is a waste of life and does not go along with the goals on animal welfare. The trade organisation of Swedish egg producers, Svenska Ägg, has long been aware of this issue but have not seen any obvious solution. In June 2018, the manager of Svenska Ägg, contacted Vreta Kluster to start solving the problem. As it was suspected that the problem could be solved by researchers at Linköping University, Vreta Kluster contacted its liaison office, which in turn facilitated a contact with researchers at the university. A meeting took place shortly after, attended by the three actors, where the issue was discussed. The researchers ended up in the idea to attack the problem 
with gas sensors. Vreta Kluster also connected the project to the innovation initiative Agtech 2030 that supported the idea with some finance at a critical phase of the project.

This first meeting started a process that included several meetings and communications between the actors, that have enabled the researchers to understand the market fit of their invention and made the poultry industry aware of the emerging solution. Hopefully this collaboration could facilitate also the commercialisation of the upcoming product. What remains now is refinement of the method into a commercial prototype and then commercialisation. The role of Vreta Kluster in this project was to intermediate between Svenska Ägg, Linköping University and Agtech 2030.

\subsection{Agtech 2030}

Agtech 2030 is a 10-year development initiative, granted by the Swedish innovation agency Vinnova in November 2018. Its mission is to create a sustainability-oriented innovation environment that is inclusive and generates significant technology-, business- and competence development, as well as new knowledge within the area of agricultural technology. Agtech 2030 draws upon resources and competencies that mirror their regional areas of strengths and focus on creation of new concepts based on, for example, sensors, digital technology and mechanics but also on new collaborations and ways of doing business. Agtech 2030 strives to become one of the world's most prominent innovation environments in agricultural technology, with the reputation of meeting key sustainability challenges through collaboration and innovation.

The initiative is built upon a regional partnership of about 20 actors, representing farmers, agtech firms, tech firms, public organisations (regional authorities and weather service) and academic research (sensor technology, sustainable development, innovation management, marketing and entrepreneurship). This partnership will grow over time as the initiative develops. Agtech 2030 is run by a process management team, a board, where the main triple helix partners are represented. Agtech 2030 is hosted by Linköping University.

Agtech 2030 operates through identification and initiation of different types of collaboration-based development projects which are co-financed by the initiative. In this work, the process management team has a crucial mediating role in facilitating the composition of the project constellations and most projects so far have sprung out of dialogues between the management team and the partners. Hence, most projects run by Agtech 2030 could be regarded as 'inhouse' by means that they are initiated and run within the partnership constellation.

\section{- The digital platform project}

The digital platform was originally developed as a solution to protect African rhinos in the wild-life park of Ngulia in Kenya. The back-end solutions were developed in the form of an app and dashboard for the rhino project. The Agtech 2030 management team saw a potential in this technology for use by farmers. Through the mediation of Agtech 2030, the rhino technology development team, that consists of researchers in sensor informatics and IT-experts, met with farmers from different farming sectors, such as livestock breeders, horse breeding and equestrian sports, and beekeepers. In the case of beekeeping, Agtech 2030 has connected the tech developing professionals with a network of people working with bee farming, and among them a professional beekeeper with a strong interest in technology. A process of developing Internet of Things solutions for beekeeping has started.

The new direction of the project strives to develop an open standard for cost efficient and robust field data collection and visualisation, tailored for farmers to keep track of both animals and equipment. This cooperation between technology developers and farmers will enable the technology applications fit to the needs of farmers. The role of Agtech 2030 in this has been to facilitate contacts between these groups of people. 


\section{Analysis and discussion}

The intermediary organisations in our three cases are built differently, as described above. While SLU Partnership Alnarp and Agtech 2030 are university-based with strong research foundations, Vreta Kluster is a regional cooperation initiative and a physical place for agri-food firm locations. Their different backgrounds affect the activities and possibilities offered by the intermediary organisations. Following the development stages described by Ungureanu et al. (2018) one can say that Agtech 2030 acts similar to the emergent model, while Vreta Kluster has more in common with the brokering model. SLU Partnership Alnarp has been around since 2004, therefore being more mature and has similarities with the platform model. However, all three organisations are engaged in: (1) forming meeting places with several actors such as seminars; and (2) specific matchmaking meetings between two or few actors. As argued by Winch and Courtney (2007) intermediary organisations should be organised on a non-for-profit basis and preferably in case of privatepublic partnerships and their reason is that this creates independence of stakeholders. Furthermore, good contacts with sources of innovative ideas are essential, and so is also their positioning in the innovation network. This holds also for the intermediary organisations studied in this paper.

Meetings with several actors, such as seminars, coffee meetings and subject groups or industry council meetings, serve the purpose of supporting agri-food firms and other actors in navigating in a complex VUCA world. Gaining information of opportunities and for reducing risks and uncertainties is important, along with building networks and making oneself known to others. These meetings also aid actors in getting to know the intermediary organisation, to build personal relations, trust and get familiar with the environment of the intermediary organisation. Besides providing subject information, this helps to lower the cultural barriers and start the social learning mentioned in Section 2 and prepare the ground for eventual value creating meetings. While Partnership Alnarp invited firms and researchers with an interest in biochar so that they could get to know each other, it could not foresee the value creating meeting that occurred between the firm and the researcher in the following workshop.

On a matchmaking level, the intermediary organisations described in Section 4, provide meetings for actors with a specific aim, i.e. trying to form value creating meetings. This was the case with the rooster egg and the digital platform projects, where the intermediary organisations brought together actors who would not have met otherwise, to meetings that resulted in substantial innovative ideas for future commercialisation. While Vreta Kluster and SLU Partnership Alnarp arrange events where information is shared among the participants, Agtech 2030 is already more focused in its set-up and scope, which allows for more directed efforts in matchmaking.

All three intermediary organisations devote efforts into forming and if needed facilitating value creating meetings. For this, a wide network is needed, and a familiarity with both agriculture and other areas that can cross fertilise the agricultural industry, such as food industry and digital technology. While SLU Partnership Alnarp and Vreta Kluster over the years have built strong reputations of trustworthiness within the agricultural sector in Sweden, partly due to familiarity and legitimacy within the industry, intermediary organisations are perhaps extra important in making connections across sectoral boundaries. Agtech 2030 makes an explicit effort to connect the agricultural industry with technological sectors and thus spanning sectoral boundaries. Agricultural intermediary organisations need to be constantly aware of and working with other areas of expertise to open up for new combinations, competence and collaborations.

Taking a closer look upon how the organisations studied have worked in the example cases, some comments could be made; regarding SLU Partnership Alnarp, it was a seminar on a specific topic that led to a contact between actors that contributed to value creation. In this chain of meetings, staff from the intermediary organisation had an active role in facilitating the dialogue. In the Vreta Kluster case, it was an organisation in the house that turned to Vreta Kluster to get a problem solved. Vreta Kluster then mediated contact with the university that started to work on the solution. Vreta Kluster also mediated contact to a financier. Both these processes could be described as generated by a market need. In the Agtech 2030 case, the digital platform 
collaborations were formed to push the technology out to new areas - i.e. from rhinos to cattle, horses and beehives. In all the three cases mediation has been crucial. Another crucial factor is, as put forward by Curran et al. (2010), knowledge - in all the three development cases the people involved have deep professional knowledge within their areas respectively. Hence it is when this knowledge is combined that 'value' is created.

Regarding how the matchmaking is conducted, our empirical examples reveal that it can take different forms. In the case of SLU Partnership Alnarp an open activity - a seminar - for knowledge exchange led to a match. In the Vreta Kluster case, it was an active search through a large network that led to a match and in the case of Agtech 2030 the matchmaking has been dependent on personal contacts of closely involved individuals. The Agtech 2030 approach could be seen as highly efficient, however, it is also the most vulnerable since it is highly dependent on sole individuals. In all three intermediary organisations the matchmaking function has, at least from time to time, been strongly tied to one or very few individuals. The advantage of this is that the processes become agile and also conducted with high precision, provided that the individual is skilled. The drawback is that the operations become vulnerable as they are dependent on very few individuals. Furthermore, the role of mediating is difficult to pinpoint and evaluate (Klerkx and Leeuwis, 2008), hence it is hard to get adequate resources allocated for this.

To summarise this analysis, we can conclude that to create value through meetings three factors seem to be important. 'Problem recognition' is essential for starting the process. We also showed that the right 'professionals', e.g. individuals from firms, farms and academia, need to meet and that someone, i.e. the intermediary organisation has to bring them together. The third factor is the 'platform' where the meeting can take place. A well-known place and a beneficial physical environment can help not only to attract professionals to attend a meeting. Inspiring environments can also make professionals feel good when the meeting has started. Frankelius and Vogel (2009) also mention meals such as lunches and dinners as strategic tools for value-creating meetings. The three crucial factors that need to be combined to create value are illustrated in Figure 1.

Based on our empirical examples, we can conclude that value created through combining these three factors can be of various type. It can lead to new constellation-based business models, innovative concepts, methods and products, increased knowledge and learning, new areas of research, identification of new market opportunities, co-branding and increased sector collaboration.

The analysis also gives ahead that value creation could be described as a four-step process (Figure 2), which includes: (1) problem recognition; (2) contact creation; (3) dialogue facilitation; and (4) value creation. The role of the innovation intermediary as facilitator is crucial in all the steps of this process.

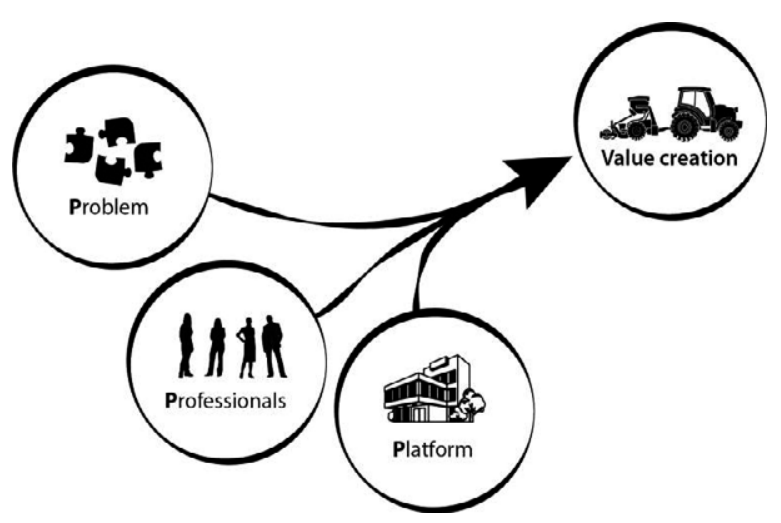

Figure 1. Problem, professionals and platform are essential value creating factors. 


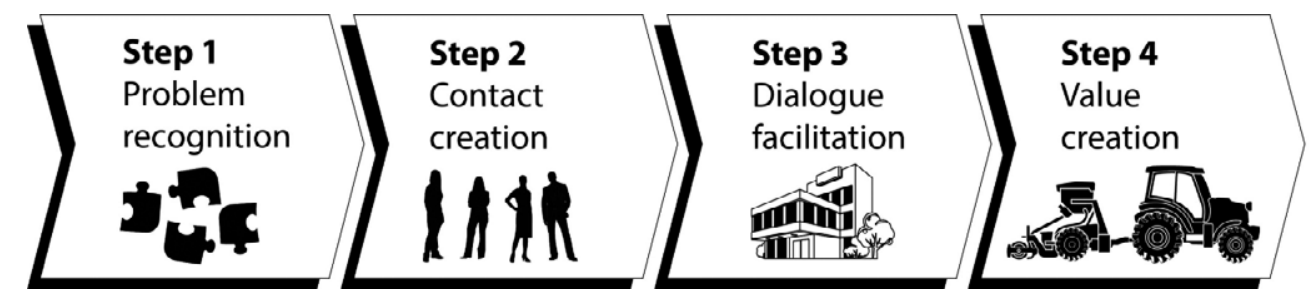

Figure 2. Facilitating value-creating meetings as a four-step process.

Finally, even though intermediaries are regarded as catalysts and facilitators of value - including or not including innovation dimensions - there are also dilemmas (Klerkx and Leeuwis, 2009). For example, quality aspects such as adequate knowledge of the intermediary could be questioned and also the mandate of the intermediary organisation. Furthermore, they could be feared to act like 'hidden messengers' of policy actors, which in turn may affect their credibility. Ungureanu et al. (2018) show that cooperation can increase complexity and uncertainty, as in VUCA, and they therefore recommend that attention also is put upon the unintended consequences of partnerships. But even if most meetings won't lead to direct value creation, it is still an important striving as meetings provide information and network expansion for the participants, which can lead further.

\section{Conclusions}

The aim of this study was to explore the concept of value creating meetings that connect agri-food firms with other crucial actors with whom they can collaborate or co-innovate, and related to this, examine the role of innovation intermediary organisations in the forming of such value creating meetings and we have reached the following conclusions:

- Value creation meetings emerge from the fusion of three important factors: problem, professionals and platform.

- Value creation is a four-step process starting with problem recognition, contact creation and dialogue facilitation and, if successful, ends with value creation.

- Collaboration between actors is a way to handle the complex world of VUCA.

In general, there is an untapped potential in professionals not meeting enough today. In a VUCA world, collaboration among actors is the new logic (Ungureanu et al., 2018) to survive and prosper. However, to be useful to agri-food firms, meetings and intermediary efforts need to be created with the aim to form value creating meetings, defined as a meeting between two or more actors that creates an innovative process that results in an economic value, either in short or long term, for at least one of the actors. Here, intermediary organisations can play an important role by building relations, trust, lower cultural barriers and starting social learning processes, that in turn opens for connecting actors with matching resources and competences.

Intermediary organisations in agri-food context have an important role in making connections across sectoral borders, e.g. with technology, digital solutions and new business models, as sectors converge (Curran et al.,2010). This, however, requires that the staff of the intermediary organisation have a border spanning competence and network. If this is the case, the agricultural industry can be connected with technological sectors and thus spanning sectoral boundaries. This implies though that agricultural intermediary organisations constantly work with other areas of expertise to open up for new combinations, competence and collaborations.

Arranging meetings, both large and small, with some intellectual investment behind, naturally requires resources. All the three intermediary organisations are led by groups of devoted, inclusive individuals with large networks of contacts. While this is an asset, it is also vulnerable to be dependent on few individuals. As the intermediary role is sometimes difficult to pinpoint, evaluate and correctly attribute (Klerkx and Leeuwis, 2008), it is hard to get adequate resources allocated for this. 
Implications for policy makers and agri-food business firms include the suggestion that intermediary organisations can play important bridging roles in a complex and fragmented context, offering contacts, networks and value creating meetings for actors. EU policy on agricultural knowledge and innovation systems brings forward the role of innovation brokering and support (EU SCAR, 2019). However, for this to work out well, intermediary organisations need to be responsive to their network and focus on forming value creating meetings, work actively across sectoral boundaries, and allocate adequate resources for mediating efforts. This, however, is not to say that all intermediary organisations play this role. In fact, there are reasons to believe that not all activities conducted by intermediary organisations promote value creation. Thus, there is a need for further research in order to bring forward more knowledge about the connection between different actions in intermediary organisations and value creation.

\section{Acknowledgements}

We are grateful to the three intermediary case studies and persons involved in the value creating meeting case studies, without whom this could not have been made. We are also grateful to Sparbanksstiftelsen Färs \& Frosta/Sparbanken Skåne, SLU Partnership Alnarp, SLU RådNu, Stiftelsen Lantbruksforskning and Vinnova who have financed this research.

\section{Conflict of interest}

The authors declare no conflict of interest. The funders had no role in the design of the study or in the decision to publish the results.

\section{References}

Adner, R. 2006. Match your innovation strategy to your innovation ecosystem. Harvard Business Review 84(4): 98.

Alvesson, M. and K. Sköldberg. 2018. Reflexive methodology. New vistas for qualitative research. Sage Publications, London, UK.

Bennett, N. and G.J. Lemoine. 2014. What a difference a word makes: understanding threats to performance in a VUCA world. Business Horizons 57(3): 311-317.

Blackmore, C., N. Sriskandarajah and R. Ison. 2018. Developing learning systems for addressing uncertainty in farming, food and environment: what has changed in recent times? International Journal of Agricultural Extension 3(15): 3-15.

Blix Germundsson, L. 2020. SLU Partnership Alnarp: connecting academia, industry and society. LTV Faculty Factsheet 2020. Swedish University of Agricultural Sciences, Alnarp, Sweden.

Blix Germundsson, L., S. Augustinsson and A. Lidén. 2020. Collaboration in the making - towards a practicebased approach to university innovation intermediary organisations. Sustainability 12(12): 5142.

Curran, C.S., S. Bröring and J. Leker. 2010. Anticipating converging industries using publicly available data. Technological Forecasting and Social Change 77(3): 385-395.

Daniels, S.E. and G.B. Walker. 2001. Working through environmental conflict. The collaborative learning approach. Praeger Publishers, Westport, CT, USA.

Duarte, D.L. and N.T. Snyder 2001. Mastering virtual teams: strategies, tools, and techniques that succeed, $2^{\text {nd }}$ edition. Jossey-Bass, San Francisco, CA, USA.

Edquist, C. (ed.) 1997. Systems of innovation; technology, institutions and organisations. Pinter, London, UK. EU SCAR. 2019. Preparing for future AKIS in Europe. European Commission, Brussels, Belgium.

Fleming, L. and D.M. Waguespack. 2007. Brokerage, boundary spanning, and leadership in open innovation communities. Organization Science 18(2): 165-180.

Frankelius, P. 2009. En teoretisk modell av värdeskapande möten [A theoretical model of value creating meetings]. In: P. Frankelius and O. Vogel (eds.) Värdeskapande möten. Liber AB, Malmö, Sweden, pp. 216-238.

Frankelius, P. and O. Vogel. 2009. Värdeskapande möten [Value creating meetings]. Liber AB, Malmö, Sweden. 
Freeman, C. 1987. Technology policy and economic performance. lessons from Japan. Pinter, London, UK. Gummesson, E. 1991. Qualitative methods in management research. Sage, London, UK.

Haslam, A.S. 2001. Psychology in organizations. Sage, London, UK.

Hayano, D.M. 1979. Auto-ethnography: paradigms, problems, and prospects. Human Organization 38 : $113-120$.

Hertel, T.W. 2015. The challenges of sustainably feeding a growing planet. Food Security 7(2): 185-198.

Hofstede, G. 1996. Organisationer och kulturer: Om interkulturell förståelse [Organizations and cultures: about intercultural understanding]. Studentlitteratur, Lund, Sweden.

Howells, J. 2006. Intermediation and the role of intermediaries in innovation. Research Policy 35(5): 715-728.

Humphreys, M. 2005. Getting personal: reflexivity and autoethnographic vignettes. Qualitative Inquiry 11(6): 840-860.

Klerkx, L. and C. Leeuwis. 2008. Matching demand and supply in the agricultural knowledge infrastructure: experiences with innovation intermediaries. Food Policy 33(3): 260-276.

Klerkx, L. and C. Leeuwis. 2009. Establishment and embedding of innovation brokers at different innovation system levels: insights from the Dutch agricultural sector. Technological Forecasting and Social Change 76(6): 849-860.

Lewin, K. 1946. Action research and minority problems. Journal of Social Issues 2: 34-46.

Lundvall, B.-A. 1992. National systems of innovation - toward a theory of innovation and interactive learning. Pinter, London, UK.

Mead, M. (ed.) 1951. Cultural patterns and cultural change. Sage, London, UK.

Neff, P.J. 1995. Cross-cultural research teams in a global enterprise. Research Technology Management 38(3): 15-20.

Norrman, C., D. Bienkowska, P. Frankelius and L. Witell. 2020. Towards a typology of cooperation-based business models in agriculture. IFAMA 30 ${ }^{\text {th }}$ World Conference 2020: Food for the Future. September 22-24, 2020. Rotterdam, the Netherlands, online.

Organisation for Economic Cooperation and Development (OECD). 2019. Innovation, productivity and sustainability in food and agriculture; main findings from country reviews and policy lessons. OECD Food and Agricultural Reviews, OECD Publishing, Paris, France.

Purdy, J.M. 2012. A framework for assessing power in collaborative governance processes. Public Administration Review 72(3): 409-417.

Reinert, K.A. 2015. Food security as basic goods provision. World Medical \& Health Policy 7: 171-186.

Sanner, L. 1997. Trust between entrepreneurs and external actors: sensemaking in organising new business ventures. PhD-thesis, Uppsala University, Uppsala, Sweden.

Schumpeter, J.A. 1934. The theory of economic development. Transaction Publishers, New Brunswick, NJ, USA.

Simon, H. 1945. Administrative behavior. Macmillan, New York, NY, USA.

Ungureanu, P., F. Bertolotti and D. Macri. 2018. Brokers or platforms? A longitudinal study of how hybrid interorganizational partnerships for regional innovation deal with VUCA environments. European Journal of Innovation Management 21(4): 636-671.

Winch, G.M. and R. Courtney. 2007. The organization of innovation brokers: an international review. Technology Analysis \& Strategic Management 19(6): 747-763.

Zambon, I., M. Cecchini, G. Egidi, M. Grazia Saporito and A. Colantoni. 2019. Revolution 4.0: industry vs. agriculture in a future development for SMEs. Processes 7(1): 36. 